\title{
靜脈性空氣栓塞に於る血壓の變動 並に潜函病の死因に就て
}

大學院學生 柏 木 謙 三 郎

[京都帝國大學醫學部耳鼻咽喉科教室(星野教授指導)]

同工藤 敏 夫

[京都帝國大學醫學部眞下丙科敎室 (真下敎授指導)]

\begin{tabular}{|c|c|c|c|}
\hline & 目 & 次 & \\
\hline 緒 & 言 & & の變化 \\
\hline 第一章 & 一般症狀证に剖檢所見 & 第四章 & 潜函病の死因に就て \\
\hline 第二章 & 静脈性空氣栓塞に於る血壓 & 結 & 論 \\
\hline & の變化 & 交 & 献 \\
\hline 第三章 & 重篤なる潜函病に於る血壓 & & \\
\hline
\end{tabular}

\section{緒言}

一般症狀並儿剖檢所見の潜函病之蒁だ “相似たるは靜胍性空㲵栓塞なり，潜函病 に於る血壓の變動に就ては㓪に述べた $b^{(1)}$. 本篇に於ては靜脈性空氣栓塞に於 る血壓の變化老測定し且潜函病の死因に 就て述べんとす。

\section{第一章 一般症狀並に剖檢所見}

一定時間高氣壓內に動物を滞留せしめ たる後, 急激なる減壓を行ふときは, 動 物は數分乃至十數分にして著しく不安狀 態を示し呼吸困難むり。分臟部に雜夏を 䆠取し重篤の場合には遂に䇟死す。之を 靜胍性空氣栓塞に比するに上述の症狀空 氣注入直後に現はる」の差異あるのみ． 剖檢上注目すべきは心臟なり、潜函病
に在りては左側心室は收縮し少量の氣泡 を存するも, 右側心房, 心室は著しく擴 大し氧泡性血液充滿し大靜脈並飞肺動脈 子氣泡性血液を以て充され著しく撗張 す.静脈性空氣栓塞に在りては庄側心房, 心室及びてれょり出づる大動脈と其分枝 內には毫子氣泡を存せざる點を溜函病と 異にす。

\section{第二章 静脈性空氣栓塞に於る 血壓の變化}

實驗動物として家鬼を使用す。山本 ${ }^{(2)}$ によれば靜脈性空㲵栓塞に於る家鬼の空

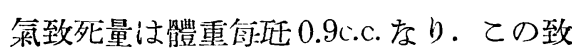
死量內に於て少量の空氣を耳緗静脈上り 徐々飞注入す. 血壓測定は前篇に述べし と同䊉の方法を肞ふ.其成續は次の如し. 


\begin{tabular}{|c|c|c|c|c|c|c|c|c|c|c|}
\hline \multirow{2}{*}{$\begin{array}{l}\text { 例 } \\
\text { 番 } \\
\text { 號 } \\
\end{array}$} & \multirow{2}{*}{$\begin{array}{c}\text { 體 } \\
\text { 重 } \\
\text { (配) } \\
\end{array}$} & \multirow{2}{*}{$\begin{array}{l}\text { 空注 } \\
\text { 気量 } \\
\text { 犝) } \\
\end{array}$} & \multirow[b]{2}{*}{ 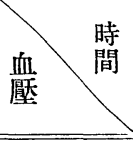 } & \multirow[b]{2}{*}{ 前 } & \multicolumn{2}{|c|}{ 空 } & \multirow{2}{*}{$\frac{\text { 注 }}{20}$} & 入 & \multicolumn{2}{|c|}{ 後 (分) } \\
\hline & & & & & 1 & 10 & & 30 & 40 & 50 \\
\hline 1 & 20 & 3.0 & 最 & 110 & 90 & 70 & \multicolumn{2}{|c|}{$\rightarrow$ unmessbar } & & \\
\hline 2 & 2.5 & 12 & & 100 & 90 & 80 & 80 & 90 & 90 & 100 \\
\hline 3 & 2.8 & 1.5 & 盖 & 110 & 90 & 80 & 80 & 90 & 100 & 100 \\
\hline 4 & 25 & 1.0 & (m.m. $\mathrm{Hg}$ ) & 110 & 90 & 80 & 80 & 80 & 90 & 100 \\
\hline 1 & & & 最 & 60 & 50 & 40 & \multicolumn{2}{|c|}{$\rightarrow$ unmessbar } & & \\
\hline 2 & & & 小 & 70 & 60 & 50 & 50 & 50 & 60 & 70 \\
\hline 3 & & & 孟垣 & 70 & 70 & 60 & 60 & 70 & 70 & 70 \\
\hline 4 & & & (m.m. Hg) & 70 & 60 & 60 & 60 & 60 & 60 & 70 \\
\hline
\end{tabular}

靜脈性空氣栓塞に在りては最大血壓は空 氣注入直後に於て著しく下降し約50分に して正常に危る．血壓の下降は觀血的方 法を以て測定せる山本 ${ }^{(2)}$, 大島(3) の成績 と一致す．而して血壓の下降は空氟注入 量多き程著明なり．最小血壓は最大血壓
に伴ひて下降す。

\section{第三章 重篤なる潜函病に於る 血壓の變化}

重篤なる潜函病に於る血壓を测定する に其成績次の如し.

\begin{tabular}{|c|c|c|c|c|c|c|c|c|c|c|c|}
\hline \multirow{2}{*}{$\begin{array}{l}\text { 例 } \\
\text { 番 } \\
\text { 號 }\end{array}$} & \multirow{2}{*}{$\begin{array}{c}\text { 體 } \\
\text { 重 } \\
\text { (聒) }\end{array}$} & \multirow{2}{*}{ 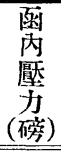 } & \multirow{2}{*}{$\begin{array}{l}\text { 帶 } \\
\text { 留 } \\
\text { 時 } \\
\text { 間 } \\
\text { (分) }\end{array}$} & \multirow{2}{*}{ 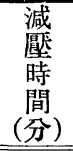 } & \multirow{2}{*}{ 血間 } & \multirow{2}{*}{$\begin{array}{l}\text { 加 } \\
\text { 壓 } \\
\text { 前 } \\
\end{array}$} & \multicolumn{2}{|c|}{ 減 } & \multicolumn{3}{|c|}{ 後（分） } \\
\hline & & & & & & & 1 & 10 & 20 & 30 & 40 \\
\hline 1 & 27 & 80 & 40 & 3 & 最 血 & 110 & 100 & 90 & 60 & 60 & $\rightarrow$ unme \\
\hline 2 & 2.5 & 80 & 50 & 1 & (m.m. Hg) & 120 & 100 & 70 & $\rightarrow$ unme & bar & \\
\hline 1 & & & & & 最 血 & 70 & 60 & 50 & 40 & $\rightarrow$ unme & bar \\
\hline 2 & & & & & (m.m. $\left.H^{\prime \prime}\right)$ & 70 & 60 & 40 & $\rightarrow$ unme & & \\
\hline
\end{tabular}

重篤なる沙函病を焱起せしむるに，血壓 は急激に下降し一定時して逐に零位之成 る其血壓下降の狀態を觀るに多量の空氣 を耳縁靜脈より注入したる場合と全く同 一なり.

\section{第四章 潜函病の死因に就て}

現今血液中の氣泡は肺臟を通過せずと は多數學者 (山本 ${ }^{(2)}$, 大島 ${ }^{(3)}$, 高崎 ${ }^{(1)}$ 等)の 認むる所にして, 靜脈性空氣栓塞の死因
に關しては腦血管栓塞說は否定せられ， 侵入氣泡の肺栓塞形成より血行を遮斷す るに基くと解せらる. 上述せし靜脈性空 氧栓塞に於る血壓の變化子亦これを裏書 きするものなり。次に潜函病の死因に就 て考察せん. Heller, Mager, v. Schrötter 等(1897) は出函後四肢の激痛, 呼吸困唯,

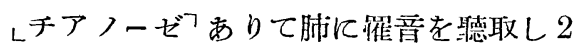
時間を經過して死亡せる潜菡夫の 2 例に 
一は肺の浮腫及充血を, 他は多量の㲵泡 を膨隆せる右側心房, 心室に證明して潜 函病の死因を血液中に發生せる氣泡を除 去せんとする心臟の過勞に歸せり．ての 他に潜函病の死因に關する說明あるを見 お.

余等は潜函病の死因に關し次の如く考 察す。潜函病に於ては急激なる減壓によ り全身血管延いて腦血管內に氣泡を發生 すべきの容易に想像し得ることは靜脈性 空氣栓塞の場合と其趣をを異にす. 從つ て稀なるべしと踓, 腦血管栓塞は潜函病 の死因となることあるべし. 然れども上. 來記述の如く（第一章，第二章，第三章 參照）重篤なる潜函病に於ては動物は彼 靜脈內空氣注入實驗の場合と全く同一の 症狀，經過の下に整れ而も剖檢上殆ど同 一なるてとょりして腦血管栓塞は潜函病 の直接の死因と關係せざるを思はしむ.

由て重䈍なる潜函病に於ては血管內に 發生せる氣泡は血流に從ひ右室を經て肺

1）柏木, 工藤：未發表.

2) 山本：静脈性空氣栓塞死の實驗的研究 北海道醫學雜誌 8 年 7 號 大日本耳鼻 367 卷 7 號，37卷 1 號. 東京醫事新誌 $2673,2674,2675$. 7 尜 1 號, 耳鼻咽喉科 1 卷 8 號

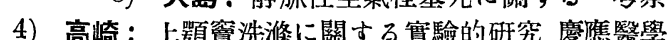
Todesursache von Presslustarbeitern. deutsch. med. Wochensch. 1897.

\section{文} 5) Heller

臟に至り肺栓塞を形成し小循環障碍の結 果動物は呼吸困難，ムチアノーゼ?，心悸 克進等を招來し肺栓塞高度なれば心臟を 機能不全に陷らしめて死を招くるのなり と思惟するを得べし.

Alt 等が氣泡の肺臟通過可能なりとし 潜函病の死因を血液中の氧泡を除去せん とする心臟の過勞に求めたるも氏等の經 驗せる 2 症例の臨床上並に剖檢上の所見 よりして余等は寧る氣泡の肺栓塞を以て 說朋するの晏當なるを思ふるのなり。

\section{結論}

1. 實驗的靜脈性空氣栓塞に於ては最 大血壓は空氣注入直後著しく下降し約50 分にして正常に杘る.

2. 潜圂病の死因は血管內に發生せる 氧泡の肺栓塞形成により血行を遮斷する 几基く.

擱筆するに當り星野㸚授の御懇篤なる御指 導前に御校閱を深謝す。

\section{獻}

3) 大島：静脈性空氣栓塞死に關する一考察 